\title{
METHANE PRODUCTION FROM BREAD KURSU AND POTATOES VINETA WASTE AND EFFECT OF CATALYST METAFERM
}

\author{
Vilis Dubrovskis, Imants Plume, Indulis Straume \\ Latvia University of Life Sciences and Technologies, Latvia \\ vilisd@inbox.lv, imants.plume@inbox.lv, indulis.straume@1lu.lv
}

\begin{abstract}
There are significant quantities of different food wastes, which cannot be consumed for food in Latvia. Foods popular in Latvia are rye bread Kursu and potatoes Vineta. The significant part of this food was diverted to waste due to non-standard, surplus production, bad storage conditions, shelf life limitations and wastes accruing during food consumption by consumers. Food wastes, when disposed in landfills, will degrade easy in aerobic conditions releasing harmful gases, including gaseous nitrogen compounds and carbon dioxide. Also, food wastes disposal in landfills are limited now and expected to be avoided in future according to the respective EU Directive on disposal of easy degradable wastes. Damaged bread and potatoes peels may be utilised in the biogas production process. There is an interest to investigate the effect of usage of additives, e.g. catalyst Metaferm, to enhance the methane production during the anaerobic fermentation process. In previous studies, the addition of catalyst Metaferm caused the improvement of methane extraction from substrates with difficultly biodegradable corn silage and dried grains. Therefore, this study continues to examine the effect of the additive Metaferm on more easily fermentable biomass. To find the methane volume obtainable from bread Kursu and potato Vineta wastes, a study was conducted in 16 bioreactors at the temperature of $38^{\circ} \mathrm{C}$. The specific methane volume $0.459 \mathrm{l} \cdot \mathrm{g}_{\text {DOM }}^{-1}$ or $0.515 \mathrm{l} \cdot \mathrm{g}^{-1}$ DOM were obtained from rye bread Kursu or potatoes Vineta respectively, after 30 days anaerobic digestion (AD) process. The addition of Metaferm increases the methane yield by $5.4 \%$ or $2.3 \%$ from rye bread or potato wastes, respectively. Investigation results show that both food wastes can be utilised in biogas plants for energy production successfully.
\end{abstract}

Keywords: methane, anaerobic fermentation, potato Vineta, rye bread Kursu, food waste.

\section{Introduction}

With the decline of fossil energy resources in the world, the renewable energy resources are increasingly being used. One of the most effective and environmentally friendly resources is biomethane obtained in the biogas purification process. The rapid development of biogas plants in Europe takes place since 2009, when 6227 biogas plants were operated, and in December 2016 there were running already 17,762 biogas and 503 biomethane plants [1].

In line with the development of biomethane plants, biomethane production has greatly increased since 2011: production rose from $752 \mathrm{GWh}$ in 2011 to $17,264 \mathrm{GWh}$ in $2016(+16,512 \mathrm{GWh})$. In 2016, the biomethane production in Europe increased by $4,971 \mathrm{GWh}(+40 \%)$ : current growth in the sector is therefore demonstrably rapid. The countries with the most significant development of biomethane production in 2016 were Germany $(+900 \mathrm{GWh})$, France $(+133 \mathrm{GWh})$ and Sweden $(+78 \mathrm{GWh})$ [1].

Stable and highly effective operation of biogas plants is ensured by properly selected and prepared feedstock [2]. In Latvia, corn silage is used less in the last years and different food waste and organic waste are used more to replace the maize silage. Literature contains a lot of data confirming that the production of biogas from different processed potato products is less compared to the biogas obtainable from raw potatoes. Usually, potatoes varieties are never mentioned in such studies, although potatoes are diverse and may produce different amounts of biogas from different varieties. The methane yield of $92 \mathrm{~m}^{3} \mathrm{t}^{-1}$ of natural mass [3] is shown without providing the data on the dry matter content and organic dry matter content in natural biomass, therefore, it is not possible to make any comparison with the results obtained by other researchers. The popular German edition Faustzahlen Biogas [4] has shown that $610 \mathrm{l} \cdot \mathrm{g}^{-1}$ DOM biogas with a methane content of $50 \%$ and $670 \mathrm{l} \cdot \mathrm{g}^{-1}$ DOM gas with a methane content of $56 \%$ can be produced from starch of crushed potatoes in the alcohol production process.

Vineta is a very popular potatoes variety used for food in Latvia, and is one of the most delicious and also highly productive varieties. In this study sample potatoes of this variety are used that did not meet the food standards and also were not suitable for use as the seed material. Previously, such potatoes were used for animal feed, but non-standard potatoes are no longer used for fodder due to industrialization of pig or cattle breeding using dry feed or silage instead in Latvia. 
Another food waste - bakery product bread Kursu is made from rye flour and is very popular in Latvia. In this study, biomass for the investigation was the samples of bread Kursu expired in the supermarket and therefore could no longer be used for food.

Our previous study with damaged bread has shown that the specific biogas volumes (methane percentage in biogas) obtained after 30 days of the anaerobic digestion (AD) process were the following: 'French bread' $0.723 \mathrm{l} \cdot \mathrm{g}^{-1}{ }_{\text {DOM }}(50.6 \%)$; 'Rye flour bread' $0.634 \mathrm{l} \cdot \mathrm{g}^{-1}{ }_{\text {DOM }}(49.9 \%)$; 'Wheat flour (coarse) bread' $0.731 \mathrm{l} \cdot \mathrm{g}^{-1}{ }_{\text {DOM }}(50.9 \%)$; 'Toaster bread' $0.694 \mathrm{l} \cdot \mathrm{g}^{-1}{ }_{\text {DOM }}(44.9 \%)$, and 'White bread' (with egg and milk additives) $0.9431 \cdot \mathrm{g}^{-1}$ DOM $(45.4 \%)$ [5]. The results show that damaged bread can be used for biogas production successfully.

Slovak researchers obtained specific biogas yield from old bread anaerobic digestion over 7001 $\mathrm{kg}^{-1} \mathrm{vs}$ in average [6].

Other researchers reported that anaerobic fermentation of old bread resulted in specific biogas yield $6501 \mathrm{~kg}^{-1} \mathrm{vs}$, and specific methane yield $3131 \cdot \mathrm{kg}^{-1} \mathrm{vs}$ [7].

In previous studies, the addition of catalyst Metaferm resulted in improvement of the methane yield from substrates with rather difficultly biodegradable corn silage and dried grains [8]. Therefore, this study will continue to explore an effect of the additive Metaferm on more easily fermentable biomass.

The purpose of investigation was to evaluate the biogas and methane production from potatoes Vineta and bread Kursu to justify whether the addition of biocatalyst Metaferm in substrates can result in any positive effect.

\section{Materials and methods}

Before fermentation, potato Vineta and rye bread Kursu samples were analysed for the dry matter and organic matter content. Data were used for calculation of organic load rates for bioreactors.

The widely applied methods [9;10] were used for the methane potential investigation in 16 experimental bioreactors (volume 0.75 litres). Fermented cattle manure (obtained from 1201 bioreactor working in continuous mode with almost finished digestate) was used as the inoculum. All bioreactors were filled with inoculums $(500 \mathrm{~g})$. Potato Vineta $(15.0 \mathrm{~g})$ sample was added in every bioreactor R2-R4; potato Vineta $15 \mathrm{~g}$ and catalyst Metaferm $1 \mathrm{ml}$ was added in every bioreactor R5R8. According to the experimental plan, $7 \mathrm{~g}$ rye bread Kursu was added in every bioreactor R9-R11; $7 \mathrm{~g}$ bread Kursu and $1 \mathrm{ml}$ Metaferm was added in every bioreactor R12-R15. Two bioreactors (R1 and R16) were filled with $500 \mathrm{~g}$ inoculums only for control, see Table 1. Accuracy for weight measurements of inoculum and substrates was $0.2 \mathrm{~g}$, and accuracy of weight measurements of the added biomass and Metaferm was $0.001 \mathrm{~g}$.

Dry organic matter (DOM) content was determined by drying the sample in a special unit at temperature $105^{\circ} \mathrm{C}$ and by ashing in the oven ("Nabertherm" type) at $550^{\circ} \mathrm{C}$. All the components were carefully mixed, and the obtained substrates were filled in bioreactors according to the experimental plan. All bioreactors were placed into a heated thermostat for anaerobic digestion (AD) in batch mode at temperature $38 \pm 0.5^{\circ} \mathrm{C}$.

Released biogas in the $\mathrm{AD}$ process was collected into gas bags and analysed for methane, carbon dioxide, oxygen and hydrogen sulphide gas contents at regular intervals using known methods $[5 ; 6]$.

The AD process was provided until release of biogas and methane almost ceases. Experimental data were registered in the log and processed by statistical data analyses program.

\section{Results and discussion}

Results of investigation of sample substrates, including inoculums, potato Vineta and bread Kursu with and without Metaferm, before starting of the AD process are shown in Table 1.

The digestate (practically finished cow manure) with very low organic matter content serves as an inoculum for providing of the AD process. Generally the AD process ceases in such inoculums alone, but there are still enough numbers of live bacteria to provide rapid degradation of the new portion of the organic matter included in the substrate at the start of the AD process. 
Biogas and methane yields from bioreactors R2-R15 with added biomass are shown in Table 2 and Fig. 2 with already subtracted average values of biogas and methane obtained from the control reactors R1 and R16 filled in with pure inoculum.

Table 1

Results of analyses of raw material samples before anaerobic digestion

\begin{tabular}{|c|c|c|c|c|c|c|c|c|}
\hline $\begin{array}{c}\text { Bio- } \\
\text { reactors }\end{array}$ & Raw material & $\begin{array}{c}\text { Weight, } \\
\mathbf{g}\end{array}$ & $\mathbf{p H}$ & $\begin{array}{c}\text { TS, } \\
\mathbf{\%}\end{array}$ & $\begin{array}{c}\text { TS, } \\
\mathbf{g}\end{array}$ & $\begin{array}{c}\text { ASH, } \\
\mathbf{\%}\end{array}$ & $\begin{array}{c}\text { DOM, } \\
\mathbf{\%}\end{array}$ & $\begin{array}{c}\text { DOM, } \\
\mathbf{g}\end{array}$ \\
\hline R1; R16 & IN & 500 & 7.27 & 2.27 & 11.35 & 16.19 & 83.81 & 9.512 \\
\hline R2-R4 & PV & 15 & - & 22.68 & 3.402 & 10.73 & 79.27 & 2.697 \\
\hline R2-R4 & IN + PV & 515 & 7.27 & 2.86 & 14.752 & 17.24 & 82.76 & 12.209 \\
\hline R5-R8 & IN + PV + MF & 516 & 7.28 & 2.86 & 14.752 & 17.24 & 82.76 & 12.209 \\
\hline R9-R11 & BK & 7 & - & 75.14 & 5.260 & 2.87 & 97.13 & 5.109 \\
\hline R9-R11 & IN + BK & 507 & 7.27 & 3.28 & 16.61 & 11.98 & 88.02 & 14.621 \\
\hline R12-R15 & IN + BK + MF & 508 & 7.28 & 3.27 & 16.61 & 11.98 & 88.02 & 14.621 \\
\hline
\end{tabular}

Abbreviations: IN - inoculum; PV-potato Vineta; BK-bread Kursu; $M F$-biocatalyst Metaferm; ASH - ashes; TS - total solids; DOM - dry organic matter (on raw substrate basis); RI-R16 bioreactors.

The production of biogas and methane from potatoes Vineta and bread Kursu with and without Metaferm and from the control reactors is presented in Table 2.

Table 2

Production of biogas and methane

\begin{tabular}{|c|c|c|c|c|c|c|}
\hline $\begin{array}{l}\text { Bio- } \\
\text { reacto } \\
\quad r\end{array}$ & Raw material & $\begin{array}{l}\text { Biogas, } \\
\text { l }\end{array}$ & $\begin{array}{c}\text { Biogas, } \\
l^{-g^{-1}}{ }_{\text {DOM }}\end{array}$ & $\begin{array}{l}\text { Methane, } \\
\text { aver. \% }\end{array}$ & $\begin{array}{c}\text { Methane, } \\
\text { l }\end{array}$ & $\begin{array}{c}\text { Methane, } \\
\mathrm{l} \cdot \mathrm{g}^{-1} \text { DOM }\end{array}$ \\
\hline R2 & $\mathrm{IN}+\mathrm{PV}$ & 2.70 & 1.001 & 48.15 & 1.30 & 0.482 \\
\hline R3 & $\mathrm{IN}+\mathrm{PV}$ & 3.40 & 1.261 & 47.09 & 1.60 & 0.593 \\
\hline R4 & $\mathrm{IN}+\mathrm{PV}$ & 3.10 & 1.149 & 41.0 & 1.27 & 0.471 \\
\hline \multicolumn{2}{|c|}{ Aver. R2-R4 I st.dev. } & $\begin{array}{c}\mathbf{3 . 0 7} \\
\pm \mathbf{0 . 3 5}\end{array}$ & $\begin{array}{l}1.137 \\
\pm 0.13\end{array}$ & $\begin{array}{l}45.35 \\
\pm 3.86\end{array}$ & $\begin{array}{c}1.39 \\
\pm 0.18\end{array}$ & $\begin{array}{l}0.515 \\
\pm 0.07\end{array}$ \\
\hline R5 & $\mathrm{IN}+\mathrm{PV}+\mathrm{MF}$ & 2.80 & 1.038 & 46.04 & 1.29 & 0.478 \\
\hline R6 & $\mathrm{IN}+\mathrm{PV}+\mathrm{MF}$ & 3.50 & 1.298 & 47.46 & 1.66 & 0.616 \\
\hline R7 & $\mathrm{IN}+\mathrm{PV}+\mathrm{MF}$ & 2.80 & 1.038 & 45.00 & 1.26 & 0.467 \\
\hline R8 & $\mathrm{IN}+\mathrm{PV}+\mathrm{MF}$ & 3.20 & 1.187 & 46.06 & 1.47 & 0.546 \\
\hline \multicolumn{2}{|c|}{ Aver.R5-R8 \pm st.dev } & $\begin{array}{c}3.08 \\
\pm 0.40\end{array}$ & $\begin{array}{l}1.140 \\
\pm 0.15\end{array}$ & $\begin{array}{l}46.21 \\
\pm 1.23\end{array}$ & $\begin{array}{c}1.42 \\
\pm 0.22\end{array}$ & $\begin{array}{l}0.527 \\
\pm 0.08\end{array}$ \\
\hline R9 & $\mathrm{IN}+\mathrm{BK}$ & 5.40 & 1.057 & 48.28 & 2.61 & 0.510 \\
\hline R10 & $\mathrm{IN}+\mathrm{BK}$ & 4.50 & 0.881 & 46.56 & 2.00 & 0.410 \\
\hline R 11 & $\mathrm{IN}+\mathrm{BK}$ & 5.10 & 0.998 & 45.71 & 2.33 & 0.456 \\
\hline \multicolumn{2}{|c|}{ Aver. R9-R11 \pm st.dev. } & $\begin{array}{c}5.00 \\
\pm 0.46\end{array}$ & $\begin{array}{l}0.979 \\
\pm 0.09\end{array}$ & $\begin{array}{l}46.88 \\
\pm 1.31 \\
\end{array}$ & $\begin{array}{c}2.34 \\
\pm 0.26 \\
\end{array}$ & $\begin{array}{l}0.459 \\
\pm 0.05\end{array}$ \\
\hline $\mathrm{R} 12$ & $\mathrm{IN}+\mathrm{BK}+\mathrm{MF}$ & 6.00 & 1.174 & 47.12 & 2.85 & 0.553 \\
\hline R13 & $\mathrm{IN}+\mathrm{BK}+\mathrm{MF}$ & 5.60 & 1.096 & 48.16 & 2.70 & 0.528 \\
\hline R14 & $\mathrm{IN}+\mathrm{BK}+\mathrm{MF}$ & 5.50 & 1.077 & 47.62 & 2.62 & 0.512 \\
\hline $\mathrm{R} 15$ & $\mathrm{IN}+\mathrm{BK}+\mathrm{MF}$ & 4.00 & 0.782 & 43.63 & 1.75 & 0.342 \\
\hline \multicolumn{2}{|c|}{ Aver. R11-R15 \pm st.dev } & $\begin{array}{c}5.28 \\
\pm 0.88 \\
\end{array}$ & $\begin{array}{l}1.032 \\
\pm 0.17\end{array}$ & $\begin{array}{l}46.86 \\
\pm 2.05\end{array}$ & $\begin{array}{c}2.47 \\
\pm 0.49 \\
\end{array}$ & $\begin{array}{l}0.484 \\
\pm 0.10\end{array}$ \\
\hline R16 & IN & 0.10 & N/A & N/A & 0.002 & N/A \\
\hline R1 & IN & 0.10 & N/A & N/A & 0.002 & N/A \\
\hline
\end{tabular}

Abbreviations: $1 \cdot g^{-1}$ Dom - litres per $1 \mathrm{~g}$ dry organic matter added (added biomass into inoculums), N/A - values not applicable for further calculations, as values from control reactors are substracted already from values of other bioreactors in this table. 
Specific biogas and methane yield from potatoes Vineta, potatoes Vineta with Metaferm, bread Kursu and bread Kursu with Metaferm is shown in Fig. 1.

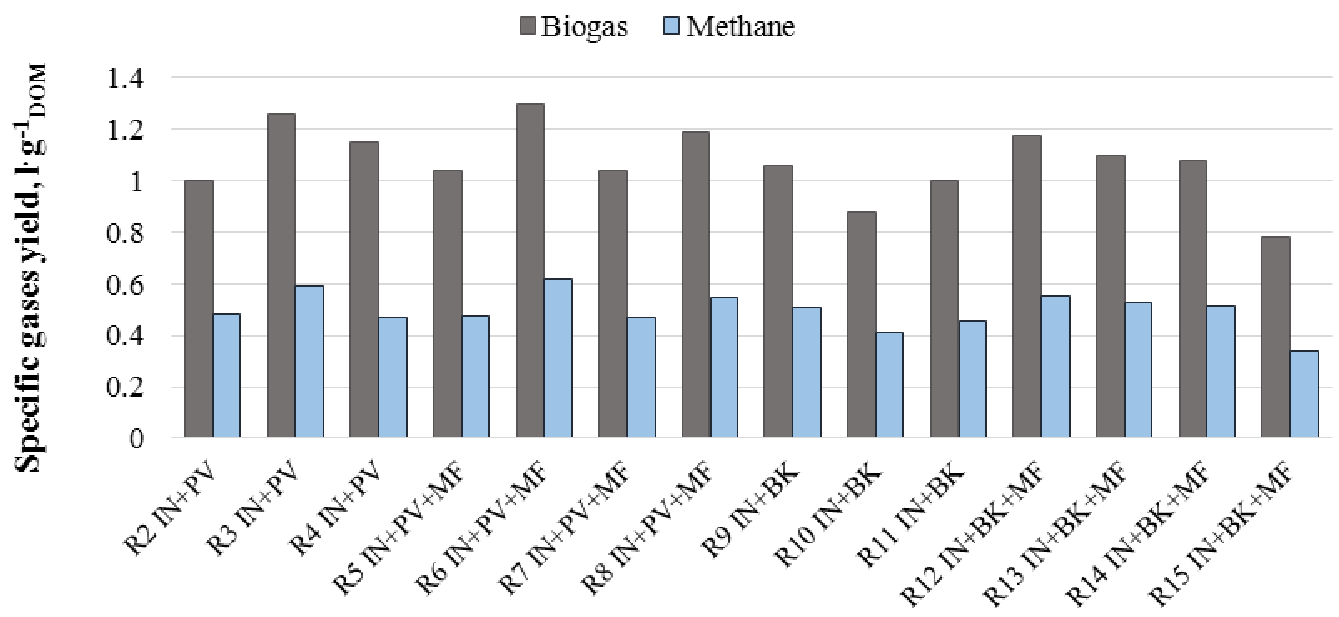

Bioreactors

Fig. 1 Specific biogas and methane yield from bioreactors: IN - inoculums; PV - potato Vineta; MF - Metaferm; BK - bread Kursu

Average methane content from potatoes Vineta, potatoes Vineta with Metaferm, bread Kursu, and bread Kursu with Metaferm is shown in Fig. 2.

$\square$ Methane $\longrightarrow$ Methane, \%

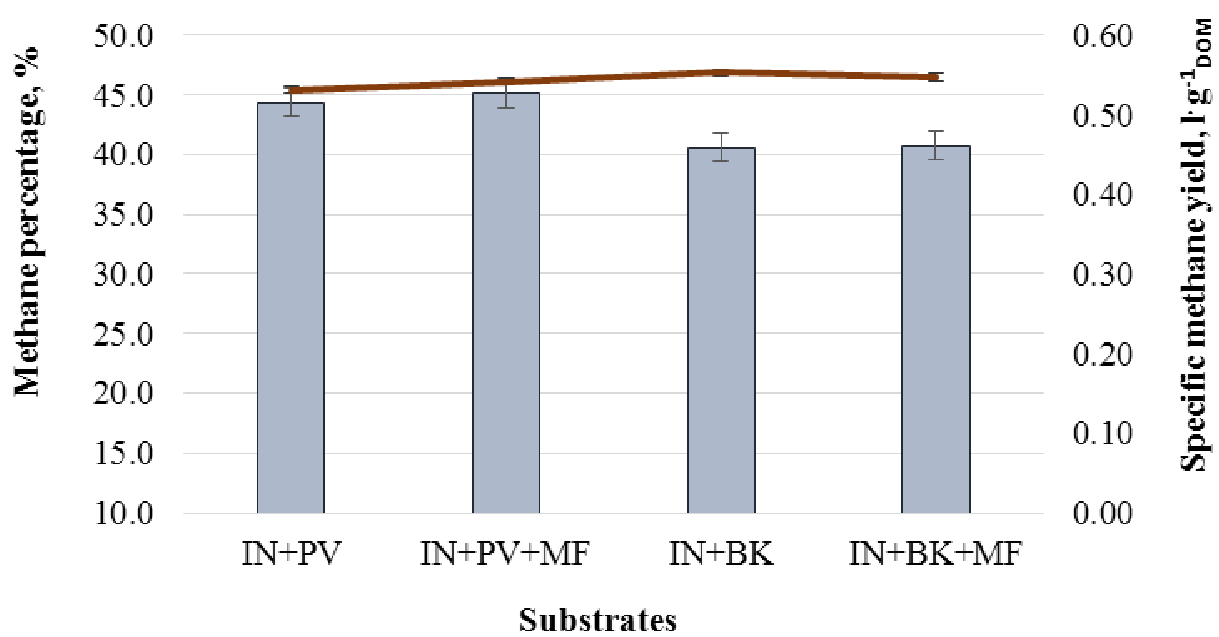

Fig. 2. Average specific methane yield and methane content for groups of substrates:

with potato Vineta; potato Vineta with Metaferm; bread Kursu; and bread Kursu with Metaferm

Methane content in biogas is obtained from all bioreactors for potatoes Vineta, but the methane content with added Metaferm was higher compared to bioreactors without Metaferm, but the methane content was not changed after adding of Metaferm to bioreactors with bread Kursu (Fig. 2). Increase of the methane content can be explained by the features of the biocatalyst Metaferm improving the bioconversion of raw materials. Increase of the methane content in biogas is always preferred, as this lowers the carbon dioxide emissions.

There are shown (Table 2 and Fig. 1) average data calculated for bioreactors containing potatoes Vineta; potatoes Vineta with Metaferm; bread Kursu; and bread Kursu with Metaferm. Specific methane yield was higher (by $5.5 \%$ ) from the substrate of bread Kursu with added $1 \mathrm{ml}$ Metaferm, and the methane yield was only slightly higher (by $2.3 \%$ ) from the substrates with potatoes Vineta with added $1 \mathrm{ml}$ Metaferm, compared with the respective substrates without the Metaferm additive. Comparison of the obtained results with other researchers' data would not be correct, as the additive 
used in this study has original composition and the substrates were composed from biomass specific in Latvia, and the substrates were investigated for the first time for the specific biomass.

\section{Conclusions}

1. Average specific methane yield from bioreactors with potatoes Vineta was $0.515 \pm 0.061 \cdot \mathrm{g}^{-1}$ DOM and the methane yield from potatoes Vineta with added $1 \mathrm{ml}$ biocatalyst Metaferm was $0.527 \pm 0.07 \mathrm{l} \cdot \mathrm{g}^{-1}$ DOM.

2. Average specific methane yield from bioreactors with bread Kursu or bread Kursu with catalyst Metaferm was $0.459 \pm 0.05 \mathrm{l} \cdot \mathrm{g}^{-1}$ DOM or $0.484 \pm 0.10 \mathrm{l} \cdot \mathrm{g}^{-1}$ DOM respectively.

3. The addition of Metaferm increases the methane yield from rye bread by $5.4 \%$ and increases the methane yield from potato wastes by $2.3 \%$.

4. Average methane content in biogas increases by $1.6 \%$ or $2.0 \%$, if the catalyst Metaferm is added in substrates with potatoes Vineta or bread Kursu, respectively.

5. The increase of average specific methane yield or methane from addition of biocatalyst Metaferm to substrates with potatoes Vineta or with bread Kursu is relatively low, and further research on the influence of different factors, e.g., individual substrate composition, anaerobic fermentation process conditions, is recommended.

\section{Acknowledgements}

This investigation was supported by the Latvian National Research Programme LATENERGI.

\section{LATENERGI}

\section{References}

[1] EBA Statistical report 2017, 120 p. [online] [18.03.2018]. Available at:http://europeanbiogas.eu/2017/12/14/eba-statistical-report-2017 - published-soon/.

[2] Dubrovskis V., Adamovičs A. Bioenerǵêtikas horizonti (Horizons of bioenergetics), Jelgava: Latvia University of Agriculture, 2012, 352 p. (In Latvian).

[3] Rutz D., Mergner R., Janssen R. Sustainable Heat Use of Biogas Plants. WIP Renewable energies, 2012, $82 \mathrm{p}$.

[4] Becker C. et al. Faustzahlen Biogas (Calculations of biogas), Publisher Kuratorium für Technik und Bauwesen in der Landwirtschaft, 2007, Darmstadt, 181 p. (In German).

[5] Dubrovskis V., Plume I. Biogas potential from damaged bread. Proceedings of International conference "Engineering for Rural Development", 2017, Jelgava, pp. 437-442.

[6] Kubaská M., Sedlácek S., Bodìk I., Kissová B. Food waste as biodegradable substrates for biogas production. Proceedings of the $37^{\text {th }}$ International Conference of Slovak Society of Chemical Engineering, 2010, Tatranské Matliare, Slovakia, pp. 1413-1418.

[7] Menardo S.,Balsar P. An Analysis of the Energy Potential of Anaerobic Digestion of Agricultural By-Products and Organic Waste.Bioenerg. Res.(5), 2012, pp. 759-767.

[8] Dubrovskis V., Plume I. Enzymatic and catalystic enchancement of methane production from corn silage and grain residues.Proceedings of International conference "Engineering for Rural Development", 2017, Jelgava, pp. 443-448.

[9] Kaltschmitt M. Methodenhandbuch (Methods Manual), 2010, Leipzig, 93 p. (In German).

[10] Mudhoo A. Biogas Production: Pretreatment Methods in Anaerobic Digestion. Wiley, 2012. $352 \mathrm{p}$. 